\title{
ONLINE LEARNING IN MASTER EDUCATIONAL ADMINISTRATION PROGRAM: STUDENT'S PERCEPTION
}

\author{
Zakaria $^{1 *}$ \\ IUniversity of Bengkulu, Bengkulu, Indonesia \\ *zakaria@yahoo.com
}

\begin{tabular}{|c|c|}
\hline Article Info & ABSTRACT \\
\hline $\begin{array}{l}\text { Article history } \\
\text { Received February 25, } 2021 \\
\text { Revised April 23, 2021 } \\
\text { Accepted April 29, } 2021 \\
\end{array}$ & $\begin{array}{l}\text { During the Covid19 epidemic that swept the world, online } \\
\text { learning has become an essential requirement in the learning } \\
\text { process. This research aims to describe the students of the } \\
\text { Educational Administration Masters Study Proaram to online }\end{array}$ \\
\hline $\begin{array}{l}\text { Keywords: Higher Education; } \\
\text { Online learning; Student } \\
\text { Perception }\end{array}$ & $\begin{array}{l}\text { learning during the Covid-19 pandemic. This research is } \\
\text { quantitative descriptive-the research population of the 1st } \\
\text { and } 2 \text { nd-semester students. Data collection techniques used } \\
\text { a questionnaire-data analysis with percentage formula. The } \\
\text { results showed that student responses to material in good } \\
\text { categories, student responses to opportunities for discussion in } \\
\text { good categories, student responses to the level of } \\
\text { understanding of the material in the categories, student } \\
\text { responses to completing assignments insufficient categories. }\end{array}$ \\
\hline
\end{tabular}

\section{INTRODUCTION}

Advances in Information and Communication technology are very beneficial for human life, making it easier for people to connect online and access information quickly. This convenience inspires the world of education to implement internet technology in learning. The learning system integrates an internet connection with the teaching and learning process known as the online learning system or virtual learning system (Bentley, Selassie, \& Shegunshi, 2012). The use of network technology and information technology is a suitable means for developing a learning system in higher education, known as the online lecture system (online) in higher education.

Since January 2020, a vocid 19 outbreak has hit the world, including Indonesia, so our Government, through the Minister of Education and Culture, issued Circular Number 36962 / MPK.A / HK / 2020 concerning online learning and working from home to prevent the spread of covid-19. This Circular stated that all teaching and learning activities both at schools and college campuses use the online method (online) to prevent the development and spread of Coronavirus disease (Covid-19). The learning process in higher education must continue accordingly with the applicable curriculum. To overcome this condition, universities develop an online or online learning system or e-learning. The Ministry of Education and Culture (2016: 4) states that online learning is an online learning interaction carried out independently by utilizing information technology and learning prepared electronically and can be done 
anytime and anywhere. This system is considered an effective means for students to study science without boundaries.

Several research results show the advantages of online learning, including Kuntarto (2017) online learning model; the online learning model has increased student absorption of course material, increasing more than $81 \%$ compared to only using face-to-face learning models. Moreover, according to Murtiyasa (2012), online learning can improve students' academic achievement and skills and reduce costs, time and energy for the learning process. Besides having advantages, it turns out that online learning also has weaknesses; according to Suyanto (2005), learning via the internet includes the lack of interaction between lecturers and students or even between students themselves. This lack of interaction can slow down the formation of values in the teaching and learning process. The learning and teaching process tends towards training rather than education. Then, not all places have internet facilities, and students do not understand the lecturers' material; discussion opportunities limited due to the limitation of study time. Nuryansyah Adijaya and Santosa (2018) stated that Online students find it more challenging to get along with miscommunication between students and lecturers often occurs, and students face problems in expressing problems in lectures to their lecturers. It is due to the lack of face-toface contact between students and lecturers (Fortune et al., 2011; Roberts \& Mclnnerney, 2007). Teaching materials have a significant role in the learning process as a source of study learning.

Online learning in the Educational Administration Masters Program is challenging work. Lecturers are not familiar with online learning using several new applications, while the demands for quality assurance of learning must carry out. Some of the disadvantages of online learning are very tough challenges for universities if they want to apply this method. The gap that occurs is evident when the application of online learning becomes mandatory. Still, in its implementation in the field, existing resources have not been able to use online media to support online learning. The gap can also see students' condition using online learning; students do not focus on the material because they are not in a learning atmosphere even though many students do not want to pay attention during conventional learning and participate actively in learning. Therefore, the purpose of this study is to describe: the responses of students of the educational administration Bengkulu University to online learning materials, the opportunity to discuss online learning, assignment of lecturers' assignments in online learning, online learning implementation time, and inhibiting factors for online learning.

The learning system integrates an internet connection with the teaching and learning process known as the online learning system or virtual learning system (Bentley, Selassie, \& Shegunshi, 2012). E-learning is a concept or learning method that utilizes digital technology 
online. In addition, education experts define e-learning as a distance learning process by combining learning principles combined with technology.

The primary purpose of using this technology is to increase the efficiency and effectiveness, transparency and accountability of learning. E-Learning uses information and communication technology as a tool, intending to increase efficiency, effectiveness, transparency, accountability and learning convenience; with its object is a better, more interesting, interactive and attractive learning service. The final result expected is an increase in student academic achievement and skills and a reduction in costs, time and energy for the learning process (Murtiyasa, 2012).

The benefits of e-learning include making it easier for students to get optimal material. Meanwhile, for learning managers, the benefits of e-learning can monitor the development of student understanding easily and quickly. This online learning can be said to be valid if it can provide services according to student needs, including:

\section{a. Improve material quality}

Students can easily access e-learning content or material. Material is the main content that students will study in various forms: powerpoints, images, audio, and audiovisual. All material can present in a complete, deeply shared digital form. It will have a very positive impact on students.

\section{b. More flexible study time}

The lecturers also often have difficulty determining the right study time. With online lecturer learning online, the lecturer can design the length of time needed to study materiallearning, so participants can flexibly determine their study time. c. Monitoring Participants' Level of Understanding teachers, e-learning can also track or monitor students' development, especially in understanding the material provided. Here, both teachers and learning managers can find a standard solution to problems in the teaching and learning process. d. Increase active participation from students Online learning allows students to be more active in conveying their ideas and critical power, which is different from conventional learning, which sometimes creates a reluctance because they directly deal with course supervisors. This online learning will engage students if the delivery of data prepared in the media is fun and easy to digest, making students want to know more. e. Improve the ability to learn independently Learning can do anytime and anywhere, providing opportunities for participants to do assignments independently. Limited interaction between students stimulates participants to complete assignments independently. Increase the ability to display information with information technology devices, challenging to do with ordinary devices (Pranoto \& Alvini, 2009).

Meanwhile, according to Bates and Wulf, the benefits of e-learning are: 1) Increasing the level of learning interaction between students and teachers or instructors (enhance interactivity), 2) Enabling learning interactions from anywhere and at any time (time and 
place flexibility), 3) Reaching students in a broad range (potential to reach a global audience), 4) Facilitating the improvement and storage of learning materials (easy updating of content as well as archivable capabilities. But in reality e-learning learning also has problems, according to Fortune, Spielman, \& Pangelinan, 2011:102) and (Roberts \& Mclnnerney, 2007) there are several problems faced in online learning; teaching materials, learning interactions, and the learning environment.

\section{METHODS}

The research method used is a descriptive method with a quantitative approach. The research location is the Educational Administration Masters Program, Faculty of Teacher Training and Education, University of Bengkulu. The study population of students of the Educational Administration Masters Study Program, FKIP, Bengkulu University. The population is the first semester and second-semester students of the educational administration master program, totalling 50 students. Because the population is less than 100 people, the entire population sampled. The data collection used a questionnaire with a scale of 4 . The assessment indicators were excellent, good, sufficient and not good. The research time is in the odd semester of $2020 / 2021$

\section{RESULT AND DISCUSSION}

\section{RESULT}

\subsection{Student Responses to Online Learning Lecturer Materials}

Learning materials have an essential role in lectures. Lecturer material in online lectures seen from the object, the systematic slide show, the depth and clarity of the material. The results of data analysis about student responses to material in online learning can be seen in Table 1.

Table 1. Student's Response to Lecturer Material

\begin{tabular}{lllllll}
\hline No & Student & \multicolumn{2}{l}{ Score } & & & Total \\
\cline { 3 - 5 } & & Very Good & Good & Enough & Not Good & \\
\cline { 3 - 5 } 1. & Semester 1 & 8 & 9 & 0 & 0 & 17 \\
2. & Semester 2 & 10 & 19 & 4 & 0 & 33 \\
3. & Total & 18 & 28 & 4 & 0 & 50 \\
& Percentage & $36 \%$ & $56 \%$ & $8 \%$ & $0 \%$ & 100 \\
\hline
\end{tabular}

Based on Table 1 above, the material presented by the lecturer in online learning is in a suitable category. The 50 students in both semester one and semester 2 stated that online learning material was excellent $36 \%$, who said $56 \%$ stated that it was enough, $8 \%$ and nothing says less good. The meaning of this statement is that the material presented by the lecturer with online learning has met the needs of the subject taught, both viewed from the systemic, 
the completeness of the material, the depth of the material studied is assessed by $92 \%$ of students very well and well.

\subsection{Student responses to the opportunity to discuss Online Learning}

The opportunity to discuss is a characteristic of interaction and communication between lecturers and students during learning. The opportunity to discuss this law from asking questions, answering questions, comment, and the opportunity to convey ideas. Based on the data analysis that has been done, the following results obtained as explained in Table 2.

Table 2. Students' responses to discussion opportunities Online Learning

\begin{tabular}{lllllll}
\hline No & Student & \multicolumn{3}{c}{ Assessment Score } & Total \\
\cline { 3 - 6 } & & Very Good & Good & Enough & Not Good nnnnnnn & \\
\cline { 3 - 6 } 1. & Semester 1 & 6 & 11 & 0 & 0 & 33 \\
2. & Semester 2 & 12 & 21 & 0 & 0 & 50 \\
3. & Total & 18 & 32 & 0 & 0 & 100 \\
& Percentage & $36 \%$ & $64 \%$ & $0 \%$ & $0 \%$ & 0 \\
\hline
\end{tabular}

Based on table 4.2. above it can explain that the implementation of online learning according to student responses still gets the opportunity to discuss with the lecturer and discussion between friends about the problems or problem topics discussed, which states excellent $36 \%$, which states either $64 \%$ and no one says enough or not good.

\subsection{Student Responses in Giving Lecturer Assignments in Online Learning}

Giving assignments to students is a task devoted to lecturers to deepen their insight and mastery of the material that students have learned by accessing other sources, both from books and e-books available in the library. Based on data analysis that has been done, the following results obtained, as explained in Table 3.

Table 3. Student's Response to the Assignment of Onli

\begin{tabular}{|c|c|c|c|c|c|c|}
\hline \multirow[t]{2}{*}{ No } & \multirow[t]{2}{*}{ Student } & \multicolumn{5}{|c|}{ Assessment Score } \\
\hline & & $\begin{array}{l}\text { Very } \\
\text { Good }\end{array}$ & Good & Enough & Not Good & Total \\
\hline 1. & Semester 1 & 6 & 11 & 0 & 0 & 17 \\
\hline 2. & Semester 2 & 12 & 21 & 0 & 0 & 33 \\
\hline 3. & Total & 18 & 37 & 0 & 0 & 50 \\
\hline & Percentage & $36 \%$ & $74 \%$ & $0 \%$ & $0 \%$ & 100 \\
\hline
\end{tabular}

Based on table 4.4 above, students' responses to assignments during online learning mostly said it was good as much as $74 \%$, and as many as $36 \%$ said it was excellent. It means that students can understand and do the assignments given by the lecturer and by accessing the material provided or using other sources that have been determined by the source either through books or e-books.

\subsection{Student Responses to Implementation Time in Online Learning}


The timing of online learning can be flexible, not necessarily according to a predetermined schedule. However, it is adjusted to the time and opportunity of lecturers and students because the implementation does not depend on the place. The timing of this implementation is very flexible. Flexible, less flexible and inflexible. Based on the data analysis that has been done, the following results obtained (Table 4).

Table 4. Student Responses at Implementation Time Online

\begin{tabular}{lllllll}
\hline No & Student & \multicolumn{3}{l}{ Assessment Score } & \multicolumn{2}{l}{ Total } \\
\cline { 3 - 6 } & & $\begin{array}{l}\text { Very } \\
\text { Flexible }\end{array}$ & Flexible & $\begin{array}{l}\text { Less } \\
\text { Flexible }\end{array}$ & $\begin{array}{l}\text { inFlexibl } \\
\text { e }\end{array}$ \\
\hline 1. & Semester 1 & 4 & 11 & 2 & 0 & 17 \\
2. & Semester 2 & 10 & 19 & 4 & 0 & 33 \\
3. & Total & 14 & 30 & 6 & 0 & 50 \\
& Percentage & $28 \%$ & $60 \%$ & $12 \%$ & $0 \%$ & 100 \\
\hline
\end{tabular}

Based on table 4 above, it can explain that students' responses to the implementation time of online learning are $28 \%$ very flexible and those who say flexible $60 \%$ and $12 \%$ flexible enough. It means that online learning is appropriate for master program students who are already working on average because they do not depend on the schedule arranged by the study program. Still, the implementation time is flexible according to the opportunities of lecturers and students.

\subsection{Student Responses to Obstacles to Implementing Online Learning}

Online learning in implementation has obstacles both in terms of internet networks, the level of depth of the material studied, the facilities owned by laptops, Android phones and costs, smooth communication between lecturers and students. The following steps can be seen in Table 5.

Table 5. Student Responses to Implementation Barriers Online Learning

\begin{tabular}{|c|c|c|c|c|c|c|}
\hline \multirow[t]{2}{*}{ No } & \multirow[t]{2}{*}{ Student } & \multicolumn{4}{|l|}{ Score } & \multirow[t]{2}{*}{ Tota } \\
\hline & & $\begin{array}{l}\text { Network } \\
\text { internet }\end{array}$ & $\begin{array}{l}\text { Depth of } \\
\text { material }\end{array}$ & Facility & interaction & \\
\hline 1. & Semester 1 & 8 & 0 & 2 & 7 & 17 \\
\hline 2. & Semester 2 & 7 & 2 & 4 & 20 & 33 \\
\hline \multirow[t]{2}{*}{3.} & Total & 15 & 2 & 6 & 27 & 50 \\
\hline & Percentage & $30 \%$ & $4 \%$ & $12 \%$ & $54 \%$ & 100 \\
\hline
\end{tabular}

The biggest obstacle faced by students in online learning is the interaction factor between students and lecturers and between students by $54 \%$, the second is the network factor of $30 \%$. In comparison, the depth factor of the material delivered by the lecturer is $4 \%$, and the facilities owned $12 \%$. It means that students still expect face-to-face (offline) learning with lecturers even though there is an online learning policy. 


\section{DISCUSSION}

The research results on the responses of students of the Educational Administration Masters study program to online learning carried out by lecturers were generally in a suitable category. Moreover, only a tiny proportion, namely $8 \%$, stated that online learning materials were in the excellent category. It means that online learning does not experience significant obstacles, and for its continuation, learning can be said to be effective. According to the researchers' opinion, the above conditions can occur because the students are adults, people who have worked, most of whom have a background of teachers or education practitioners, even school principals involved in the world of education every day. The results of this study are in line with the research of Aan Widiyono (2020) that the majority of students in the Unisnu Jepara Study Program take online lectures at home using a gadget (cellphone) with a data connection in a pretty good internet signal. Apart from the advantages and disadvantages of online learning that universities have carried out, universities are supposed to be the pioneers of technology-based learning along with the demands of realizing a 21 stcentury learning community. The Covid-19 outbreak causes online learning, but online learning has become a demand for the world of education. Since the last few years $(\mathrm{He}, \mathrm{XU}$, \& Kruck, 2019).

Moreover, online education was promoted to become mainstream in 2025 (Palvia et al., 2018). The results of Sanjaya's research (2020) examines the reflection of online learning during the Covid-19 emergency (Huda et al., 2018). Through online learning, higher education will create a modern learning environment (Huda et al., 2018; Maulana \& Hamidi, 2020) who explain that online lectures students have alternatives and require variations in learning, and they prefer online learning as a variety of ways to develop and deliver the material.

Online learning has several advantages. However, there are several obstacles during the online lecture process; among them, students want variations between online learning and offline learning to meet face-to-face with their lecturers in presenting the material to interact more intently in discussing material, discussing and expanding student insight by providing input on student questions. The internet signal during the implementation of online lectures is still not optimal because the average signal is still in the medium and low signal category, especially coupled with unpredictable weather, frequent rain; some student home areas are not good internet access, which adds to the lack of smooth implementation of online learning.

\section{CONCLUSIONS}

Based on the results of research and discussion, the general conclusions of this study are: The responses of students to online learning saw from the aspects of the material, 
discussion opportunities, assignments, understanding of lecture material in suitable categories. At the same time, the specific conclusions are 1. Student responses to online learning lecturer material, which stated in excellent $36 \%$, good. $56 \%$ and enough at $8 \%, 2$. Response to discussion opportunities in online learning which stated $36 \%$ very good and reasonable. by $64 \%$. 3. Student responses in understanding lecturer material in online learning which stated $30 \%$ excellent and $70 \%$ good, 4 . Student responses to assignments in online learning that stated very good were $36 \%$, and those who said they were good $64 \%, 5$. Student responses to the implementation time of online learning stated excellent $28 \%$, both $60 \%$ and $12 \%$ sufficient, 6 . Students online learning barriers include $44 \%$ network disruption, $28 \%$ student interaction with lecturers, $10 \%$ depth of material, and $18 \%$ technology use skills.

\section{REFERENCE}

Bates, T. \& Wulf. 1997. The Impact of Technological Change on Open and Distance Learning. Distance Education.

Bentley, Y., Selassie, H., \& Shegunshi, A. 2012. Design and evaluation of student-focused eLearning. Electronic Journal of E-Learning, 10(1), 1-12. https://doi.org/10.1007/s10648013-9243-1.

Kuntarto, E. (2017). Keefektifan Model Pembelajaran Daring Dalam Perkuliahan Bahasa Indonesia Di Perguruan Tinggi. Jurnal, IJEIL. Vol 3.No.1. ISSN online: 2502-2261.

Fortune, M. F., Spielman, M., \& Pangelinan, D. T. 2011 . Students' Perceptions of Online or Face-to-Face Learning and Social Media in Hospitality, Recreation and Tourism. MERLOT Journal of Online Learning and Teaching, $7(1)$.

He, W., Xu, G., \& Kruck, S. E. (2019). Online IS education for the 21st century. Journal of Information Systems Education, 25(2), 1. https://aisel.aisnet.org/jise/vol25/iss2

Kementerian Pendidikan dan Kebudayaan Rl.2014.Panduan Pengembangan dan Penyelenggaraan KDITT, Jakarta: Kemendikbud..

Kemendikbud - Dirjen GTK, 2016. Guru Pembelajar - Petunjuk Teknis Moda Dalam Jaringan (Daring).

Murtiyasa, B. 2012. Pemanfaatan Teknologi Informasi dan Komunikasi Untuk Meningkatkan Kualitas Pembelajaran Matematika. Surakarta : FKIP Univ. Muhammadiyah.Surakarta.[On-Line].Tersedia:

http://physicsmaster.orgfree.com/ArtikelJurnalPendidikan/TIK.

Pranoto, A. (2009). Sains dan Teknologi. Jakarta : Gramedia Pustaka Utama.

Palvia, S., Aeron, P., Gupta, P., Mahapatra, D., Parida, R., Rosner, R., \& Sindhi, S. (2018). Online education: Worldwide status, challenges, trends, and implications. https://doi.org/10.1080/1097198X.2018.1542262 
Santosa, L. P. (2018). Persepsi Mahasiswa Dalam Pembelajaran Online. (Volume 10 No. 2 September $2018 \quad$ P-ISSN 2086-6151,E-ISSN,2579-3438.http:// ejournal.bsi.ac.id/ejurnal/index.php/wanastra) Universitas Esa Unggul, Jakarta.

Suyanto, A. H. (2005). Mengenal E-Learning. Universitas Gadjah Mada. [On-Line]. Tersedia : http:www.asep-hs.web.ugm.ac.id.

He, W., Xu, G., \& Kruck, S. E. (2019). Online IS education for the 21st century. Journal of Information Systems Education, 25(2), 1. https://aisel.aisnet.org/jise/vol25/iss2

Sanjaya, R..(2020). 21 Refleksi Pembelajaran Daring di Masa Darurat. SCU Knowledge Media. Widiyono, A. 2020. Efektifitas Perkuliahan Daring (Online) pada Mahasiswa PGSD di Saat Pandemi Covid 19 Jurnal Pendidikan, Vol. 8, No. 2, Tahun 2020 ISSN: 2337-7607 eISSN: 2337-7593 169 PGSD, FTIK, UNISNU Jepara. 